\title{
MODEL PEMBELAJARAN OTENTIK DALAM MATA PELAJARAN PAI
}

\author{
Syaefudin Achmad \\ IAIN Salatiga \\ saefudinachmad1991@gmail.com
}

\begin{abstract}
Islamic education is a very important subject to make the learners understand the religion of Islam perfectly. But in reality, the purpose of Islamic religious education subjects is not always achieved. The average learner only understands the theories in Islamic religious education subjects as well as practicing them. They have not been able to practise theory in everyday life. Authentic learning methods can be an alternative to realize the objective of learning to study the Islamic education in the maximum. An authentic learning Model is a learning that allows students to explore, discuss, and establish meaningful concepts and relationships, involving real problems and projects relevant to learners and Implemented through several stages.
\end{abstract}

Keywords: Learning Model, Authentic, Islamic Education

\begin{abstract}
Abstrak: Pendidikan Agama Islam adalah mata pelajaran yang sangat penting untuk mewujudkan peserta didik memahami agama islam secara sempurna. Namun dalam kenyataannya, tujuan dari mata pelajaran Pendidikan Agama Islam tidak selalu tercapai. Rata-rata peserta didik hanya memahami teori-teori dalam mata pelajaran Pendidikan Agama Islam serta mempraktikkannya. Mereka belum bisa mengamalkan teori dalam kehidupan sehari-hari. Metode pembelajaran otentik bisa menjadi alternatif untuk mewujudkan tujuan pembelajaran mata pelajaran Pendidikan Agam Islam secara maksimal. Model pembelajaran otentik merupakan pembelajaran yang memungkinkan peserta didik menggali, mendiskusikan, dan membangun secara bermakna konsep-konsep dan hubungan-hubungan, yang melibatkan masalah nyata dan proyek yang relevan dengan peserta didik dan dilaksanakan melalui beberapa tahapan.
\end{abstract}

Kata Kunci: Model Pembelajaran, Otentik, PAI

\section{A. Pendahuluan}

Mata Pelajaran PAI (Pendidikan agama Islam) adalah mata pelajaran wajib di sekolah karena keberadannya sangat dibutuhkan bagi peserta didik yang beragama Islam, agar dapat memahami secara benar ajaran Islam sebagai agama yang sempurna (kaamil). Kesempurnaan ajaran Islam yang dipelajari secara integral (kaaffah) diharapkan dapat meningkatkan kualitas peserta didik sebagai bagian dari umat Islam dalam keseluruhan aspek kehidupanya. Agar ajaran Islam dapat dipelajari secara efektif dan efisien, maka perlu dikembangkan kurikulum pendidikan agama Islam sesuai dengan 
perkembangan dan tuntutan zaman. ${ }^{1}$ Pendidikan agama Islam tidak hanya mengarah pada kehidupan akhirat semata, namun juga kehidupan duniawi. Pendidikan agama Islam dituntut untuk bisa berperan aktif di dalam kemajuan zaman sehingga pembaharuan kurikulum pendidikan agama Islam sangat diperlukan untuk menjawab tuntutan zaman. Untuk bisa mewujudkan tujuan pendidikan agama Islam, tentunya diperlukan sebuah model pembelajaran yang baik. Model pembelajaran PAI yang baik diharapkan mampu membuat peserta didik menjadi intelektual yang beriman dan bertaqwa, sehingga mampu menjalankan syari'at Islam sesuai dengan tuntutan al-Qur'an dan hadits, serta memiliki akhlak dan budi pekerti yang mulia sesuai dengan norm-norma yang ada di masyarakat. Kesimpulannya pembelajaran PAI bertujuan agar peserta didik menjadi seorang yang religius dan nasionalis, berguna bagi agama, bangsa dan negara. ${ }^{2}$

Belum tercapainya tujuan pembelajaran PAI secara maksimal bisa disebabkan karena munculnya problematika di dalam pembelajaran PAI. Problem lain dari pembelajaran PAI sebagaimana hasil penelitian dari Susiana, di SMKN Turen yang terdapat pada peserta didik diantaranya kurangnya minta peserta didik, masih banyak peserta didik yang tidak bisa membaca dan menulis Al-Qur'an, orang tua kurang memberikan pendidikan Islam di rumah. Sedangkan problematika pada guru diantaranya minimnya kompetensi guru, terbatasnya jumlah guru, dan tidak memiliki pengetahuan yang luas tentang materi. ${ }^{3}$

Menurut Muslimin, problamatika yang dialami oleh guru PAI cukup kompleks. Problematika guru PAI meliputi probelamtika tingkat rendah dan sedang. Problematika tingkat rendah meliputi persoalan yang berhubungan dengan materi pembelajaran. Problematika tingkat sedang meliputi persoalan yang berkaitan dengan perumusan tujuan pembelajaran, pemilihan metode, serta penggunaan media. ${ }^{4}$

\footnotetext{
${ }^{1}$ Draf Permenag Kurikulum 2013 Mata Pelajaran Pendidikan Agama Islam Dan Bahasa Arab Di Madrasah, hlm. 5.

2 Sadam Fajar Shodiq, "Revival Tujuan Pembelajaran Pendidikan Agama Islam (PAI) di Era Revolusi Industri 4.0, At-Tajdid, Vol. 2, No. 2, 2018, hlm. 221.

${ }^{3}$ Susiana, "Problematika Pembelajaran PAI di SMKN 1 Turen, Jurnal Ath-Thariqah, Vol. 2, No. 1, 2017, hlm. 87-88.

${ }^{4}$ Muslimin, "Problematika Pembelajaran PAI dan Upaya Guru PAI dalam Pembinaannya di Sekolah", Tarbawiyah: Jurnal Pendidikan Agama Islam,_Vol. 1, No. 2, 2017, hlm. 217
} 
Mata pelajaran PAI memiliki karakter yang tidak dimiliki oleh mata pelajaran yang lain dimana ada aspek being (keberagamaan) yang menjadi tujuan pembelajaran mata pelajaran PAI, selain tentunya ada aspek knowing (pemahaman agama Islam) dan doing (melaksanakan ajaran agama). Kegagalan mata pelajaran PAI selama ini dikatakan karena belum mampu mencapai aspek being. Peserta didik banyak yang sukses memahami ajaran agama dan bisa melaksanakan ajaran itu, tetapi mereka belum semuanya mampu menjalankan ajaran Islam tersebut dalam kehidupan sehari-hari. ${ }^{5}$

Tidak tercapainya aspek being ini disebabkan oleh faktor-faktor seperti model pembelajaran yang tidak tepat, serta kompetensi guru yang tidak maksimal. Model pembelajaran yang tidak tepat serta tidak mampunya guru mengimplementasikan sebuah model pembelajaran dengan baik dapat membuat aspek being mata pelajaran PAI tidak tercapai.

Penulis menawarkan sebuah model pembelajaran yang diharapkan mampu membuat aspek being dalam mata pelajaran PAI bisa tercapai. Salah satu model pembelajaran yang diharapkan bisa merealisasikan aspek itu adalah model pembelajaran otentik. Model pembelajaran otentik ini merupakan model diatur sedemikian rupa sehingga lingkungan mirip dengan dunia nyata. Jadi dalam mata pelajaran PAI, pembelajaran tidak hanya berkutat kepada teori-teori yang terdapat di dalam buku pelajaran, namun materi-materi PAI langsung diimplementasikan di kehidupan nyata sebagai aktivitas rutin sehari-hari sehingga aspek being nantinya bisa tercapai.

Tulisan ini akan memaparkan tentang bagaimana mengimplementasikan model pembelajaran otentik dalam mata pelajaran PAI di sekolah. Tulisan ini diharapkan bisa menjadi pedoman para guru untuk mencoba menerapkan model pembelajaran otentik dengan harapan bisa memksimalkan tujuan pembelajaran PAI.

\section{B. Definisi Model Pembelajaran}

Menurut Komarudin sebagaimana yang dikutip oleh Hidayat, Model dapat dipahami sebagai: (1) suatu tipe atau desain; (2) suatu deskripsi atau analogi yang

${ }^{5}$ Muhammad Iwan Abdi, "Contextual Teaching And Learning (Ctl) Dalam Pembelajaran PAI", Jurnal Dinamika Ilmu, Vol 11, No.1, 2011, hlm. 6. 
dipergunakan untuk membantu proses visualisasi sesuatu yang tidak dapat dengan langsung diamati; (3) suatu sistem asumsi-asumsi, data-data, dan informasiinformasi yang dipakai untuk menggambarkan secara matematis suatu obyek atau peristiwa; (4) suatu desain yang disederhanakan dari suatu sistem kerja, suatu terjemahan realitas yang disederhanakan; (5) suatu deskripsi dari suatu sistem yang mungkin atau imajiner; dan (6) penyajian yang diperkecil agar dapat menjelaskan dan menunjukkan sifat bentuk aslinya. ${ }^{6}$

Pembelajaran pada hakikatnya merupakan proses komunikasi transaksional yang bersifat timbal balik, baik antara guru dengan peserta didik, antara peserta didik dengan peserta didik untuk mencapai tujuan yang telah ditetapkan. Komunikasi transaksional merupakan bentuk komunikasi yang dapat diterima, dipahami dan disepakati oleh pihak-pihak yang terkait dalam proses pembelajaran sehingga menunjukkan adanya perolehan, penguasaan, hasil, proses atau fungsi belajar bagi si peserta belajar. ${ }^{7}$ Proses komunikasi berjalan dua arah antara guru dengan peserta didik serta antara peserta didik dengan peserta didik. Sumber ilmu tidak hanya datang dari guru, namun juga dari peserta didik. Guru lebih berperan sebagai fasilitator di dalam proses pembelajaran.

Definisi lain tentang pembelajaran, yaitu suatu sistem artinya suatu keseluruhan yang terdiri dari komponen-komponen yang berinteraksi antara satu dengan lainnya dan dengan keseluruhan itu sendiri untuk mencapai tujuan pengajaran yang telah ditetapkan sebelumnya. Adapun komponen-komponen tersebut meliputi tujuan pendidikan dan pengajaran, peserta didik dan peserta didik, tenaga kependidikan khususnya guru, perencanaa pengajaran, strategi pengajaran, media pengajaran, dan evaluasi pengajaran. ${ }^{8}$

Menurut Joyce \& Weil sebagaimana yang dikutip oleh Hidayat, model pembelajaran adalah suatu rencana atau pola yang dapat digunakan untuk membentuk kurikulum (rencana pembelajaran jangka panjang), merancang bahanbahan pelajaran, dan membimbing pembelajaran di kelas atau yang lain. Model pembelajaran di susun berdasarkan prinsip-prinsip pembelajaran, teori-teori

${ }^{6}$ Hidayat, "Model Pembelajaran Pendidikan Agama Islam Berorientasi Pengembangan Karakter Bangsa", Journal El-Hikmah,Vol. 9 No. 2, 2013, hlm. 153

7Salamah, "Pengembangan Model-Model Pembelajaran Alternatif Bagi Pendidikan Islam (Suatu AlternatifSoIusi Permasalahan Pembelajaran Agama Islam), FIKRAH, Vol. 5, No.1, 2006, hlm. 17.

${ }^{8}$ Fory A. Naway, Strategi Pengelolaan Pembelajaran, (Gorontalo: Idea Publishing, 2016), hlm. 20. 
psikologis, sosiologis, analisis sistem, atau teori-teori lain yang mendukung untuk mencapai tujuan pembelajaran yang diharapkan. ${ }^{9}$ Model pembelajaran menurut Trianto didefinisikan sebagai sebuah kerangka konseptual yang menggambarkan prosedur yang sistematis dalam mengorganisasikan pengalaman belajar, untuk mencapai tujuan belajar tertentu dan berfungsi sebagai pedoman bagi perancang pembelajaran dan para guru dalam merancang dan melaksanaan pembelajaran. ${ }^{10}$

Secara sederhana, berdasarkan pendapat para ahli tentang definisi model pembelajaran, dapat disimpulkan bahwa model pembelajaran merupakan desain atau rancangan dari suatu pembelajaran yang dirancang berdasarkan prinsip-prinsip pembelajaran atau teori-teori yang mendukung dalam rangka mencapai tujuan dari pembelajaran. Oleh karena itu, dalam sebuah model pembelajaran mengandung rangkaian pendekatan, strategi, metode, serta teknik pembelajaran.

Model pembelajaran dapat dijadikan pola pilihan, artinya para guru boleh memilih model pembelajaran yang sesuai dan efisien untuk mencapai tujuan pendidikannya.11 Pemilihan model pembelajaran disesuaikan dengan kebutuhan, kondisi peserta didik, serta kompetensi guru. Pemilihan model pembelajaran yang tepat dapat mempermudah untuk mencapai tujuan pembelajaran.

Model pembelajaran memiliki beberapa jenis. Berdasarkan porsi keterlibatan antara guru dan peserta didik, model pembelajaran dibagi menjadi dua macam: Pertama, model pembelajaran yang berpusat pada guru. Model pembelajaran ini mempunyai landasan-landasan teori belajar sosial, teori belajar behavioral, dan teori pemrosesan informasi. Model pembelajaran yang berpusat pada guru difokuskan pada tatap muka aktual antara guru dan peserta didik, dengan cara menerangkan dan sebagainya. Kedua, model pembelajaran yang berpusat pada peserta didik. Model ini berpijak dari pendekatan pembelajaran yang berpusat pada peserta didik. Model ini berlandaskan asumsi yang berbeda tentang mengajar dan belajar. ${ }^{12}$

\footnotetext{
${ }^{99}$ Hidayat, "Model Pembelajaran Pendidikan Agama Islam Berorientasi Pengembangan Karakter Bangsa", Journal El-Hikmah,Vol. 9 No. 2, 2013, hlm. 153

${ }^{10}$ Trianto, Model Pembelajaran Terpadu, (Jakarta: Bumi Aksara, 2012), hlm. 53.

${ }^{11}$ Rusman, Model-Model Pembelajaran: Mengembangkan Profesionalisme Guru, (Jakarta: Rajawali Pres, 2010), hlm.133.

${ }^{12}$ Muhammad Fathurrohman dan Sulistyorini, Belajar dan Pembelajaran, (Jogjakarta: Teras, 2012), hlm. 90 .
} 


\section{Definisi PAI}

Pendidikan agama adalah pendidikan yang memberikan pengetahuan dan membentuk sikap, kepribadian, dan keterampilan peserta didik dalam mengamalkan ajaran agamanya, yang dilaksanakan sekurang-kurangnya melalui mata pelajaran/kuliah pada semua jalur, jenjang, dan jenis pendidikan. ${ }^{13}$ Pendidikan agama, khususnya agama Islam di sekolah umum terkenal dengan mata pelajaran PAI (pendidikan agama Islam), sedangkan di madrasah terbagi menjadi mata pelajaran Fiqih, Qur'an Hadits, Sejarah Kebudayaan Islam, serta Akidah Akhlak.

PAI dibakukan sebagai nama kegiatan mendidikkan agama Islam. PAI sebagai mata pelajaran seharusnya dinamakan Agama Islam, karena yang diajarkan adalah agama Islam. Nama kegiatannya atau usaha-usaha dalam mendidikkan agama Islam disebut sebagai pendidikan agama Islam. Pendidikan Islam adalah nama sistem, yaitu sistem pendidikan yang islami, yang memiliki komponen-komponen yang secara keseluruhan mendukung terwujudnya sosok muslim yang di idealkan. Pendidikan Islam ialah pendidikan yang teori-teorinya disusun berdasarkan al-Qur an dan Hadits. ${ }^{14}$

Pendidikan Agama Islam adalah satu dari sekian mata pelajaran yang diajarkan di dunia akademik, namun akan berbeda ketika pembelajaran ini diajarkan di sekolah yang bukan berbasis Islam. Pada sekolah yang berbasis Islam tentu pembelajaran ini akan jauh lebih terperinci, nantinya akan dipecah menjadi beberapa bagian lagi seperti: pembelajaran aqidah, akhlak, al-Qur'an, hadis dan mata pelajaran yang berinduk kepada pelajaran Agama Islam. Pelajaran Agama Islampun juga akan diajarkan di sekolah-sekolah yang bukan berbasis Islam, tentunya akan dikemas lebih ringkas. ${ }^{15}$

Pendidikan Agama Islam merupakan usaha berupa bimbingan dan asuhan terhadap anak didik agar kelak setelah selesai pendidikannya dapat memahami dan mengamalkan ajaran agama Islam serta menjadikannya sebagai pandangan hidup (way of life). Pendidikan Agama Islam juga dapat diartikan sebagai pendidikan yang

${ }^{13}$ Draf Permen No. 55 Tahun 2007, hlm. 2.

${ }_{14}$ Desi Susanti, "Pengembangan Pendidikan Agama Islam", Edureligia, Vol. 1, No. 1, 2017, hlm. 65.

${ }^{15}$ Sadam Fajar Sodiq, "Revival Tujuan Pembelajaran Pendidikan Agama Islam (PAI) Di Era Revolusi Industri 4.0, At-Tajdid, Vol. 2, No. 2, 2018, hlm. 221. 
dilaksanakan berdasarkan ajaran Islam. ${ }^{16}$ Pendidikan Agama Islam (PAI) adalah usaha sadar untuk menyiapkan peserta didik agar memahami ajaran Islam (knowing), terampil melakukan ajaran Islam (doing),dan mengamalkan ajaran Islam dalam kehidupan sehari-hari (being). Adapun tujuan pendidikan agama Islam di sekolah umum adalah untuk meningkatkan pemahaman, keterampilan melakukan, dan pengamalan ajaran Islam dalam kehidupan sehari-hari. Tujuan utama pendidikan agama Islam di sekolah ialah keberagamaan, yaitu menjadi muslim yang sebenarnya. Keberagamaan inilah yang selama ini kurang di perhatikan. Karakteristik utama PAI adalah banyaknya muatan komponen being, di samping sedikit komponen knowing dan doing. Hal ini menuntut perlakuan pendidikan yang banyak berbeda dari pendidikan bidang studi umum. ${ }^{17}$ Karakter beda inilah yang membuat tidak mudah untuk mencapai tujuan mata pelajaran PAI, terutama aspek being.

Berdasarkan pendapat-pendapat tentang definisi pendidikan agama Islam tersebut, dapat disimpulkan bahwa di dalam pendidikan agama Islam memiliki beberapa unsur, diantaranya: Pertama, adanya usaha untuk merubah pribadi peserta didik agar dapat memahami dan mengamalkan ajaran agama Islam baik yang bersifat individual maupun sosial. Usaha tersebut tercermin dari proses pendidikan yang terdapat di lembaga-lembaga pendidikan. Kedua, memiliki tujuan. Tujuan dari pendidikan Islam adalah menyiapkan generasi-generasi Islam yang memiliki kompetensi knowing (memahami ajaran islam, setelah mengetahui kemudian adalah doing (melakukan apa yang dipahami dari Islam), kemudian being (mengamalkan nilai-nilai Islam di tengah masyarakat).

\section{Problematika Pembelajaran PAI}

Menurut Muhaimin, sebagaimana yang dikutip oleh Desi Susanti, pemahaman tentang PAI di sekolah dapat dilihat dari dua sudut pandang, yaitu PAI sebagai aktivitas dan PAI sebagai fenomena. PAI sebagai aktivitas berarti upaya yang secara sadar dirancang untuk membantu seseorang atau sekelompok orang dalam

${ }^{16}$ Fitri Oviyanti, Inovasi Pembelajaran Pai Dengan Pengembangan Model Constructivism Pada Jenjang Pendidikan Dasar Dan Menengah, Ta'dib, Vol. Xviii, No. 1, 2013, hlm. 109.

${ }^{17 M u h a m m a d}$ Iwan Abdi, "Contextual Teaching And Learning (Ctl) Dalam Pembelajaran PAI", Jurnal Dinamika Ilmu, Vol 11, No.1, 2011, hlm. 6. 
mengembangkan pandangan hidup (bagaimana orang akan menjalani dan memanfaatkan hidup dan kehidupannya), sikap hidup, dan keterampilan hidup baik yang bersifat manual (petunjuk praktis) maupun mental dan sikap sosial yang bernapaskan atau dijiwai oleh ajaran serta nilai-nilai Islam. Sedangkan sebagai fenomena adalah peristiwa perjumpaan antara dua orang atau lebih dan/atau penciptaan suasana yang dampaknya ialah berkembangnya suatu pandangan hidup yang bernafaskan atau dijiwai oleh ajaran dan nilai-nilai Islam, yang diwujudkan dalam sikap hidup serta keterampilan hidup pada salah satu atau beberapa pihak. ${ }^{18}$

Tujuan dari pendidikan agama Islam bisa dicapai dari proses pembelajaran yang terdapat di dalam lembaga pendidikan baik formal, non formal, maupun informal. PAI di sekolah menurut Sunhaji merupakan salah satu materi pelajaran yang dapat dijadikan dasar pengembangan nilai, pencegahan, dan sekaligus sebagai pembentukan moral peserta didik khusunya di sekolah-sekolah yang peserta didiknya berusia remaja. Usia remaja adalah anak yang sedang berkembang dan mencari jati diri. Adapun mata pelajaran PAI merupakan salah satu mata pelajaran yang dapat dijadikan pondasi pendidikan untuk mendasari serta membentengi dari hal-hal yang amoral bagi remaja yang sedang mencari jati diri. Dengan demikian, PAI diharapkan memberi kontribusi bagi terbentuknya manusia Indonesia yang beriman, bertaqwa, cerdas dan terampil. ${ }^{19}$

Proses pembelajaran Pendidikan Agama Islam (PAI) di sekolah saat ini menurut Asmaun Sahnan masih sebatas sebagai proses penyampaian "pengetahuan tentang agama Islam." Hanya sedikit arahnya pada proses internalisasi nilai-nilai Islam pada diri peserta didik, hal ini dapat dilihat dari proses pembelajaran yang dilakukan oleh guru masih dominan pada ceramah. Proses internalisasi tidak secara otomatis terjadi ketika nilai-nilai tertentu sudah dipahami oleh peserta didik. Artinya, metode ceramah yang digunakan oleh guru ketika mengajar pendidikan agama Islam (PAI) berpeluang besar gagalnya proses internalisasi nilai-nilai agama Islam pada diri peserta didik. dengan demikian perlu dipikirkan metode atau pembelajaran lain yang lebih memberikan peluang untuk terjadinya internalisasi nilai-nilai Islam tersebut. Salah satu 
pendekatan yang dapat dijadikan alternatif untuk itu adalah pendekatan pembelajaran kontekstual. ${ }^{20}$

Dalam mewujudkan aspek knowing dan doing, guru PAI tidak gagal. Mereka banyak gagal pada pembinaan aspek keberagamaan (being). Peserta didik bisa memahami ajaran agama Islam, terampil melaksanakan ajaran itu, tetapi mereka sebagiannya tidak melaksanakan ajaran Islam tersebut dalam kehidupannya seharihari. Mereka memahami hukum dan cara shalat lima, terampil melaksanakan shalat lima,tetapi sebagian dari murid itu tidak melaksanakan shalat lima. Mereka tahu konsep jujur, mereka tahu cara melaksanakan jujur, tetapi sebagian dari mereka tetap sering tidak jujur dalam kehidupannya sehari-hari. Jadi, aspek keberagamaan itulah yang sangat penting untuk ditingkatkan. ${ }^{21}$

Senada dengan pendapat di atas, menurut Hidayat, praktik pembelajaran PAI selama ini hanya memperhatikan aspek kognitif semata dari pertumbuhan kesadaran nilai-nilai (agama), dan mengabaikan pembinaan aspek afektif, yakni kemauan dan tekad untuk mengamalkan nilai-nilai ajaran agama. ketidak-seimbangan itu mengakibatkan terjadi kesenjangan antara pengetahuan dan pengamalan, antara teori dan praktik dalam kehidupan nilai agama, atau dalam praktik pendidikan agama berubah menjadi pengajaran agama, sehingga tidak mampu membentuk pribadi-pribadi bermoral, padahal intisari dari pendidikan agama adalah pendidikan moral. ${ }^{22}$

Problematika lain dari pembelajaran PAI sebagaimana hasil penelitian dari Susiana, di SMKN Turen yang terdapat pada peserta didik diantaranya kurangnya minta peserta didik, masih banyak peserta didik yang tidak bisa membaca dan menulis Al-Qur'an, orang tua kurang memberikan pendidikan Islam di rumah. Sedangkan problematika pada guru diantaranya minimnya kompetensi guru, terbatasnya jumlah guru, dan tidak memiliki pengetahuan yang luas tentang materi. ${ }^{23}$

${ }^{20}$ Asmaun Sahnan, "Pembelajaran Pendidikan Agama Islam Dengan Pendekatan Kontekstual", El-Hikmah, Vol Viii, No. 2, 2013, hlm. 218.

${ }^{21}$ Muhammad Iwan Abdi, "Contextual Teaching And Learning (Ctl) Dalam Pembelajaran PAI", Dinamika Ilmu, Vol 11 No. 1, 2011, hlm. 6.

${ }^{22}$ Hidayat, "Model Pembelajaran Pendidikan Agama Islam Berorientasi Pengembangan Karakter Bangsa", Journal El-Hikmah,Vol. 9 No. 2, 2013, hlm. 152.

${ }^{23}$ Susiana, "Problematika Pembelajaran PAI di SMKN 1 Turen, Jurnal Ath-Thariqah, Vol. 2, No. 1, 2017, hlm. 87-88. 
Menurut Muslimin, problamatika yang dialami oleh guru PAI cukup kompleks. meliputi problematika tingkat rendah dan sedang. Problematika tingkat rendah meliputi persoalan yang berhubungan dengan materi pembelajaran. Problematika tingkat sedang meliputi persoalan yang berkaitan dengan perumusan tujuan pembelajaran, pemilihan metode, serta penggunaan media. ${ }^{24}$

Kesimpulannya, yang menjadi problematika pembelajaran PAI adalah belum tercapainya tujuan pembelajaran PAI karena meskipun bisa mencapai aspek knowing dan doing, tetapi masih sulit untuk mencapai aspek being.Tidak tercapainya asek being disebabkan oleh problematika lain seperti guru PAI yang tidak berkompeten, peserta didik yang kurang antusias, serta pemilihan model pembelajaran atau media yang kurang tepat. Meskipun pemilihan model pembelajaran sudah tepat, tapi kalau guru tidak bisa mengimplementasikan model pembelajaran tersebut dengan tepat, hasil pembelajaran kurang maksimal.

\section{E. Model Pembelajaran Otentik dalam PAI}

Salah satu alternatif model pembelajaran yang kemungkinan besar mampu untuk membuat peserta didik bisa mendapat aspek being adalah model pembelajaran otentik. Menurut Donovan, Bransford \& Pallegrino (1999) sebagaimana yang dikutip oleh Clif Mims, Pembelajaran otentik (authentic learning) merupakan pendekatan pembelajaran yang memungkinkan peserta didik menggali, mendiskusikan, dan membangun secara bermakna konsep-konsep dan hubungan-hubungan, yang melibatkan masalah nyata dan proyek yang relevan dengan peserta didik. ${ }^{25}$

Pembelajaran otentik biasanya berfokus pada dunia nyata, masalah yang kompleks dan solusi mereka, kegiatan berbasis masalah, studi kasus, sebuah pembelajaran dengan lingkungan mirip dengan dunia nyata seperti mengelola kota, bangunan rumah, menerbangkan pesawat terbang, menetapkan anggaran, memecahkan kejahatan. ${ }^{26}$

${ }^{24}$ Muslimin, "Problematika Pembelajaran PAI dan Upaya Guru PAI dalam Pembinaannya di Sekolah", Tarbawiyah: Jurnal Pendidikan Agama Islam,_Vol. 1, No. 2, 2017, hlm. 217

${ }^{25} \mathrm{Clif}$ Mims, "Authentic Learning: A Practical Introduction \& Guide for Implementation", Meridian: A Middle School Computer Technologies Journal a service of NC State University, Raleigh, NC Volume 6, Issue 1, 2003, hlm. 2.

${ }^{26}$ Marilyn M. Lombardi, "Authentic Learning for the 21st Century: An Overview", Jurnal Educause, Vol .1, 2007, hlm. 2. 
Menurut Donovan sebagaimana yang dikutip oleh Marilyn M. Lombardi, pembelajaran otentik berbeda dengan pembelajaran tradisional. Pembelajaran otentik memiliki beberapa karakteristik, diantaranya: ${ }^{27}$

1. Pembelajaran berpusat pada tugas-tugas otentik yang menarik bagi peserta didik.

2. Peserta didik terlibat dalam proses eksplorasi dan penyelidikan.

3. Pembelajaran menggunakan pendekatan interdisipliner.

4. Pembelajaran terkait dengan dunia di luar kelas.

5. Peserta didik terlibat dalam tugas-tugas kompleks dan ketrampilan berfikir tingkat tinggi seperti analisis, sintesis, merancang, memanipulasi dan mengevaluasi informasi.

6. Peserta didik menghasilkan produk yang bisa dibagikan dengan orang lain.

7. Guru, orang tua, serta tenaga ahli membantu dan melakukan pembinaan dalam proses pembelajaran.

8. Peserta didik menggunakan teknik scaffolding. Menurut Bruner sebagaimana yang dikutip oleh Ratnawati Mamin, Scaffolding sebagai suatu proses dimana seorang peserta didik dibantu menuntaskan masalah tertentu melampaui kapasitas perkembangannya melalui bantuan dari seorang guru atau orang lain yang memiliki kemampuan yang lebih. ${ }^{28}$

9. Peserta didik memiliki kesempatan untuk aktif dalam kehidupan sosial.

Model pembelajaran otentik memiliki esensi dapat digunakan sebagai acuan bagi para pendidik. Esensi dalam dalam aktivitas belajar otentik meliputi sepuluh esensi. Model pembelajaran otentik bisa menjadi salah satu alternatif pembelajaran PAI. Pembelajaran PAI dengan model pembelajaran otentik bisa diartikan sebagai sebuah pembelajaran PAI yang diatur sedemikian rupa sehingga lingkungan mirip dengan dunia nyata. Jadi materi PAI tidak hanya berkutat kepada teori-teori yang terdapat di dalam buku pelajaran, namun materi-materi PAI langsung diimplementasikan di kehidupan nyata sebagai aktivitas rutin sehari-hari.

${ }^{27}$ Clif Mims,...hlm. 2.

${ }_{28}$ Ratnawati Mamin, "Penerapan Metode Pembelajaran Scaffolding Pada Pokok Bahasan Sistem Periodik Unsur", Chemica, Volume 10, No. 2, 2008, hlm. 57. 
Marilyn M. Lombardi mengungkapkan sepuluh esensi pembelajaran otentik yaitu: 1) Real-world Relevance; 2) Ill-defined Problem; 3) Sustained Investigation; 4) Multiple Source and Perspective; 5) Collaboration; 6) Reflection (metacognition); 7) Interdiciplinary Prespective; 8) Integrated Assessment; 9) Polished Product; dan 10) Multiple Interpretation and outcomes 29. Berdasarkan sepuluh esensi tersebut maka pembelajaran PAI menggunakan model pembelajaran otentik dapat dilakukan sebagai berikut:

1. Real-world Relevance. Materi PAI di dalam proses pembelajaran dibuat sedekat mungkin dengan kenyataan yang terkait dengan materi PAI. Proses pendekatan materi PAI dengan dunia nyata PAI bisa dengan cara menempatkan proses pembelajaran tidak di kelas, namun di tempat-tempat yang terkait dengan materi-materi PAI seperti di masjid.

2. Ill-defined Problem. Pemberian tugas pada pembelajaran PAI kepada peserta didik dibuat yang tidak mudah dan penuh dengan tantangan agar kemampuan peserta didik meningkat. Misalnya materi tentang zakat. Pemberian tugas kepada peserta didik bisa dengan menugaskan peserta didik untuk praktek membayar secara langsung, baik zakat fitrah maupun zakat mal.

3. Sustained Investigation. Pembelajaran PAI tidak hanya berhenti di saat jam pelajaran, namun terus berkelanjutan dan dipantau oleh guru. Guru perlu membuat tugas portofolio bagi peserta didik terkait pengamalan ibadah peserta didik sehari-hari.

4. Multiple Source and Perspective. Pembelajaran PAI memakai sumber yang majemuk. Tidak hanya bersumber dari buku mata pelajaran PAI yang telah ditetapkan, namun bisa bersumber dari internet, majalah islam, kitab-kitab klasik, serta sumber-sumber pengetahuan Islam yang lain.

5. Collaboration. Evaluasi pembelajaran PAI tidak hanya berdasarkan nilai ulangan harian atau ujian akhir semester dari masing-masing peserta didik, namun nilai-nilai dari materi PAI yang terimplementasikan dalam aktivitas sehari-hari juga dieavaluasi.

${ }_{29}$ Marilyn M. Lombardi, "Authentic Learning for the 21st Century: An Overview", Jurnal Educause, Vol .1, 2007, hlm. 3. 
6. Reflection (metacognition). Pembelajaran PAI diusahakan bisa membuat peserta didik mampu merefleksikan materi-materi PAI di dalam kehidupan sehari-hari. Guru bisa memberi tugas kepada peserta didik untuk menceritakan pengalaman dalam mengimplementasikan materi-materi PAI di dalam kehidupan sehari-hari.

7. Interdiciplinary Prespective. Sistem penilaian materi PAI dibuat jangan yang memuat jawaban benar-salah, namun dibuat yang memunculkan interpretasi serta pendapat yang berbeda dari para peserta didik. Guru bisa menggunakan metode diskusi untuk bisa mendengar pendapat-pendapat yang berbeda tentang materi PAI dari peserta didik.

8. Integrated Assessment. Penilaian juga dibuat dalam pembelajaran PAI jangan hanya berdasarkan nilai-nilai ulangan harian atau ujian semester, namun tugas yang membuat peserta didik bisa merefkleksikan ke dalam aktifitas sehari-hari, seperti tugas portofolio atau laporan kegiatan pengamalan materi-materi PAI dalam kehidupan sehari-hari.

9. Polished Product. Pembelajaran PAI dengan model pembelajaran otentik tidak hanya berjalan sesuai dengan jam pelajaran mata pelajaran PAI tanpa menghasilkan sesuatu yang bermanfaat, namun mampu menghasilkan sebuah produk yang bisa memberikan manfaat baik untuk diri sendiri maupun orang lain.

10. Multiple Interpretation and outcomes. Pembelajaran tidak hanya menerapkan prinsip-prinsip serta prosedur-prosedur dalam pembelajaran PAI, namun pembelajaran yang membuat munculnya berbagai interpretasi dari peserta didik serta solusi-solusi dari perbedaan interpretasi peserta didik.

\section{F. Kelebihan dan Kekurangan Model Pembelajaran Otentik}

Penulis mencoba menelaah tentang sisi kelebihan dari model pembelajaran otentik, dibanding model pembelajaran lain berdasarkan teori model pembelajaran otentik. Berikut beberapa kelebihan model pembelajaran otentik berdasarkan analisa penulis: Pertama, peserta didik tidak merasa jenuh dan bosan dalam mengikuti pembelajaran karena pembelajaran tidak harus diselenggarakan di kelas, namun dapat diselenggarakan di mana saja, termasuk di luar ruangan. Kedua, peserta didik 
tidak hanya memahami materi yang disampaikan oleh guru, namun juga meiliki keterampilan yang lebih dalam menganalisis wacana dan perilaku sosial. Ketiga, peserta didik mempunyai pengalaman belajar yang mumpuni karena diharuskan bisa berinteraksi dengan lingkungan sekitarnya. Keempat, peserta didik bisa memaksimalkan potensinya, bisa memahami materi secara utuh dan luas karena pembelajaran berpusat pada peserta didik.

Selain kelebihan, penulis juga mencoba menelaah sisi kekurangan dari model pembelajaran otentik berdasarkan teori model pembelajaran otentik. Berikut kekurangan model pembelajaran otentik berdasarkan analisa penulis: Pertama, pembelajaran otentik cenderung hanya dapat dilakukan pada peserta didik yang memiliki taraf intelegensi diatas rata-rata sehingga pembelajaran berjalan secara aktif. Untuk peserta didik yang intelegensinya di bawah rata-rata, model pembelajaran otentik sulit diterapkan. Kedua, tidak semua materi pelajaran dapat menggunakan pembelajaran otentik. Pasalnya, materi yang sesuai dengan pembelajaran otentik bersifat studi sosial seperti materi PAI. Ketiga, model pembelajaran otentik memerlukan waktu, biaya, dan tenaga ektra dari peserta didik sehingga tidak setiap sekolah mampu menyelenggarakan model pembelajaran otentik.

Setiap model pembelajaran yang ada masing-masing memiliki kelebihan dan kekurangan. Dengan berbagai kekurangannya, model pembelajaran otentik bisa menjadi sebuah model pembelajaran yang patut dijadikan salah satu model pembelajaran PAI melihat PAI merupakan mata pelajaran yang meiliki ciri yang berbeda dengan mata pelajaran lain seperti sains yang tujuannya hanya sebatas aspek knowing dan doing. Dengan aspek doing yang merupakan tujuan dari mata pelajaran PAI, model pembelajaran tidak bisa disamakan dengan mata pelajaran yang lain. Harus ada model pembelajaran yang bisa mencapai aspek being dalam mata pelajaran PAI. Salah satu model pembelajaran otentik bisa dijadikan alternatif dalam rangka mencapai aspek being dalam pembelajaran PAI, meskipun belum semua lembaga pendidikan mampu untuk menerapkan model pembelajaran otentik dalam mata pelajaran PAI mengingat prosedur pembelajaran yang tidak sederhana serta memerlukan biaya yang mahal. 


\section{G. Kesimpulan.}

Model pembelajaran otentik merupakan model pembelajaran yang berfokus pada dunia nyata, masalah yang kompleks dan solusi mereka, kegiatan berbasis masalah, studi kasus, sebuah pembelajaran dengan lingkungan mirip dengan dunia nyata. Model pembelajaran otentik diharapkan bisa menjadi alternatif sebuah model pembelajaran yang mampu menjawab tidak tercapainya tujuan pembelajaran PAI yang bisa disebabkan oleh faktor guru, peserta didik, serta tidak tepat dalam memilih model, media, dan metode pembelajaran. Tidak tercapainya tujuan pembelajaran materi PAI bisa dilihat dari aspek being yang belum tercapai pada peserta didik. Ketidakmampuan model pembelajaran yang lain dalam mencapai aspek being dalam pembelajaran mata pembelajaran PAI diharapkan dapat tercapai bila menggunakan model pembelajaran otentik.

Tak bisa dipungkiri bahwa tidak semua lembaga pendidikan mampu menerapkan model pembelajaran otentik ini karena cukup sulit dan butuh fasilitas yang memadai. Akan tetapi, model pembelajaran otentik bisa menjadi sebuah tawaran yang menarik bagi guru untuk menerapkan model pembelajaran otentik dalam pembelajaran PAI.

\section{DAFTAR PUSTAKA}

Fajar , Sadam Shodiq, “Revival Tujuan Pembelajaran Pendidikan Agama Islam (PAI) di Era Revolusi Industri 4.0, At-Tajdid, Vol. 2, No. 2, 2018.

Fathurrohman, Muhammad dan Sulistyorini, Belajar dan Pembelajaran, Jogjakarta: Teras, 2012.

Hidayat, "Model Pembelajaran Pendidikan Agama Islam Berorientasi Pengembangan Karakter Bangsa", Journal El-Hikmah, Vol. 9, No. 2, 2013.

Iwan, Muhammad Abdi, "Contextual Teaching And Learning (Ctl) Dalam Pembelajaran PAI", Jurnal Dinamika Ilmu, Vol 11, No.1, 2011.

Lombardi, Marilyn M, "Authentic Learning for the 21st Century: An Overview", Jurnal Educause, Vol. 1, 2007.

Mamin, Ratnawati, "Penerapan Metode Pembelajaran Scaffolding Pada Pokok Bahasan Sistem Periodik Unsur", Chemica, Volume 10, No. 2, 2008. 
Mims, Clif, "Authentic Learning: A Practical Introduction \& Guide for Implementation", Meridian: A Middle School Computer Technologies Journal a service of NC State University, Raleigh, NC Volume 6, Issue 1, 2003.

Muslimin, "Problematika Pembelajaran PAI dan Upaya Guru PAI dalam Pembinaannya di Sekolah", Tarbawiyah: Jurnal Pendidikan Agama Islam,_Vol. 1, No. 2, 2017.

Naway, Fory A, Strategi Pengelolaan Pembelajaran, Gorontalo: Idea Publishing, 2016.

Permen No. 55 Tahun 2007.

Permenag Kurikulum 2013 Mata Pelajaran Pendidikan Agama Islam Dan Bahasa Arab Di Madrasah.

Oviyanti, Fitri, Inovasi Pembelajaran Pai Dengan Pengembangan Model Constructivism Pada Jenjang Pendidikan Dasar Dan Menengah", Ta'dib, Vol. xviii, No. 1, 2013.

Rusman, Model-Model Pembelajaran: Mengembangkan Profesionalisme Guru, Jakarta: Rajawali Pres, 2010.

Sahnan, Asmaun, "Pembelajaran Pendidikan Agama Islam Dengan Pendekatan Kontekstual", El-Hikmah, Vol. viii, No. 2, 2013.

Salamah, "Pengembangan Model-Model Pembelajaran Alternatif Bagi Pendidikan Islam (Suatu Alternatif Solusi Permasalahan Pembelajaran Agama Islam)", FIKRAH, Vol. 5, No.1, (2006): 107-139.

Sunhaji, Pembelajaran Tematik-Integratif, Yogyakarta: Pustaka Senja, 2016.

Susanti, Desi, "Pengembangan Pendidikan Agama Islam", Edureligia. Vol. 1, No. 1, 2017.

Susiana, "Problematika Pembelajaran PAI di SMKN 1 Turen, Jurnal Ath-Thariqah, Vol. 2, No. 1, 2017.

Trianto, Model Pembelajaran Terpadu, Jakarta: Bumi Aksara, 2012. 